\title{
Fatty Acid Composition of Phospholipids in Human Serum Lipoprotein Fractions
}

\author{
Akira Yamamoto, M D, Katsunori Ishikawa, M D, Yuji Matsuzawa, M D, \\ Susumu Misugi, M D, Hiroshi Suda, M D and Taku Yamamura, M D
}

Running title: Phospholipid Fatty Acids in Hyperlipemia

\begin{abstract}
The major fatty acids of sphingomyelin in human serum are palmitic (16:0) and nervonic $(24: 1)$ acids. There was a marked difference in distribution of fatty acids between lipoprotein fractions in normal subjects. The concentration of 24:1 and the other long chain fatty acids with carbon chain length no less than 22 was significantly higher in a fraction containing high density lipoproteins (HDL) than in another fraction containing low and very low density lipoproteins (LDL). The LDL fraction was rich in 16:0. The difference in fatty acid composition of sphingomyelin between these two lipoprotein fractions was not marked in cases of hyperlipidemia, mostly because of a decrease in $24: 1$ in HDL fraction. There was a considerable increase in concentration of behenic acid (22:0) in HDL fraction in some cases of hyperlipidemia. LDL fraction seems to be more strict in selecting molecular species of sphingomyelin than HDL. The fatty acid composition of phosphatidylcholine (lecithin) was essentially the same for HDL and LDL fractions.
\end{abstract}

Key Words: Hyperlipidemia, Lipoproteins (high density), Lipoproteins (low density), Fatty acids (in serum lipoproteins), Sphingomyelin (in human serum), Lipids (in serum lipoproteins), Lecithin (in serum lipoproteins)

Lecithin and sphingomyelin are two major components of phospholipid in serum. These phospholipids are distributed unevenly among different lipoprotein classes. High density lipoproteins (HDL) are rich in lecithin and low density lipoproteins (LDL) contain a larger amount of sphingomyelin than $\mathrm{HDL}^{1,2)}$. There is a close association between the concentration of sphingomyelin and cholesterol in serum almost independent of the distribution pattern of lipoprotein classes ${ }^{3)}$.

Sphingomyelin is a complex lipid which shows a specific distribution to the surface membrane of tissue cells $\mathrm{s}^{4,5)}$. Aortic tissue

Received for publication December 27, 1976.

Reprints request to: Akira Yamamoto, The

Second Department of Internal Medicine, Osaka University Medical School, 1-50, 1.

chome Fukushima, Fukushima-ku, Osaka 553, Japan. shows a steady increase in sphingomyelin by aging ${ }^{6-8)}$. One of the characteristics of this surface membrane lipid is the presence of saturated or monoenoic fatty acids with carbon chain length of 22-24 in high concentration $^{9-11)}$.

It is the purpose of the present investigation to measure the distribution pattern of molecular species of sphingomyelin among different lipoprotein fractions in normal subjects and its change in hyperlipidemia. The selection of molecular species of complex lipids is one of the decisive factors for the function of a biological membrane ${ }^{12,13)}$. Discussion will be made on the role of synthesis of sphingomyelin with long chain fatty acids as a regulatory factor for the pathogenesis of hyperlipidemia. 


\section{MATERIALS AND METHODS}

Blood samples were obtained after overnight fasting from normal subjects of both sexes aged between 30 and 45 and from cases of hyperlipidemia with mild coronary heart disease and allied disorders. Serum was separated after the blood was left standing at room temperature for two hours. Lipoproteins were separated from $3 \mathrm{ml}$ of serum into (1) high density plus very high density lipoproteins (HDL fraction) and (2) low density plus very low density lipoproteins (LDL fraction) by using heparin-manganese ion precipitation method described by Burstein ${ }^{14}$. The procedure was carried out after diluting the serum with an equal volume of saline. In case the lipid concentration was high and the precipitation of LDL fraction appeared to be incomplete, the sample was further diluted with an increasing volume of saline. Heparin and manganese ion were added in proportion to the volume of the sample. The separation of the two fractions was judged to be complete semiquantitatively on agarose gel and cellulose acetate membrane electrophoresis with lipid staining and densitometry. The recovery of cholesterol from the supernatant of the reaction mixture containg HDL and lipid free protein fractions (obtained by ultracentrifugation at $d>1.063$ ) was $98-99 \%$. Fresh serum was always used in this experiment, because a considerable amount of HDLcholesterol is precipitated with heparin after serum is frozen or kept at $4^{\circ} \mathrm{C}$ for a long time before use. Srinivasan et $\mathrm{al}^{15)}$ suggested that HLD interact with heparin in the presence of $\mathrm{Mn}^{++}$, leading to the precipitation of $25 \%$ of HDL. Their experiment was done by using an isolated HDL fraction from pooled serum. Burstein and Samaille have mentioned that HDL precipitates when the fraction is isolated and dialyzed against buffered distilled water ${ }^{14}$. Quantitative recovery of HDL-cholesterol was reported by Wilson and Spiger ${ }^{16)}$ and recently confirmed by Ishikawa et $\mathrm{al}^{17)}$.
Lipids were extracted with 15 volumes of chloroform-methanol $2: 1(\mathrm{v} / \mathrm{v})$ and washed by the method of Folch et $\mathrm{al}^{18)}$. Cholesterol was determined by the method of Zurkowski ${ }^{19)}$ and phospholipids by modified Chen's method ${ }^{20,21)}$ for each lipoprotein fraction. The isolation of lecithin was performed on silicic acid thin layer chromatography $(\mathrm{TLC})^{22,23)}$. An aliquot of the sample containing $160 \mu \mathrm{g}$ of total phospholipids was applied on one plate, and 2-4 plates were used for each sample. The plates were developed with chloroformmethanol-28\% aqeous ammonia-water 120: $80: 10: 5$ into the first dimension and with chloroform - acetone - methanol - acetic acidwater $100: 40: 30: 20: 12$ into the second dimension. For analysis of sphingomyelin, samples were first subjected to mild alkaline hydrolysis according to the method of Dawson et $\mathrm{al}^{24)}$. The unsaponifiable matter containing sphingomyelin was concentrated and applied on silicic acid TLG. Plates were developed with chloroform-acetonemethanol-acetic acid-water 100:40:30:20: 12 (single dimension). Spots of TLG were visualized with rhodamine- $6 \mathrm{G}$, scraped and transfered into a culture tube with a teflone-coated screw cap. Samples were methanolyzed with $2-3 \mathrm{ml}$ of $14 \%(\mathrm{w} / \mathrm{v})$ boron trifluroride in methanol at $100^{\circ}$ for $30 \mathrm{~min}$ (for lecithin) or $90 \mathrm{~min}$ (for sphingomyelin). Treatment of samples were carefully done under an atmosphere of nitrogen. The recovery of phospholipids from spots on TLC was $95-100 \%$ by phosphorus assay and the recovery of sphingolipids by sphingosine assay was $93-97 \%$. The recovery of a polyunsaturated fatty acid (G 22:6, $\omega-3$ ) after methanolysis by this procedure was $97 \%$, although a longer treatment caused a considerable loss of unsatureted fatty acids (20\% for oleic acid, C 18:1, after 5 hours). Methylesters of fatty acids were analyzed on GLC. Samples from sphingomyelin which were essentially free of polyunsaturated fatty acids were analyzed on a column of $3 \% \mathrm{SE}-30$ on Gaschrom $Q$ at $220^{\circ}$. The recovery of monoenoic fatty acids was complete and the analyses at $210^{\circ}-230^{\circ}$ gave 
Phospholipid Fatty Acids in Hyperlipemia

Table 1. Serum concentrations of cholesterol and phospholipids and their distribution between high and low density lipoprotein fractions in normal and hyperlipidemic subjects

\begin{tabular}{|c|c|c|c|c|c|c|c|c|c|c|c|}
\hline \multirow[b]{2}{*}{ Group } & \multirow[b]{2}{*}{ Case } & \multirow{2}{*}{$\begin{array}{l}\text { Age } \\
\text { and } \\
\text { Sex }\end{array}$} & \multicolumn{4}{|c|}{ Cholesterol (mg/100 ml serum) } & \multicolumn{4}{|c|}{ Phospholipids (mg $/ 100 \mathrm{ml}$ serum) } & \multirow{2}{*}{$\begin{array}{c}\text { Trigly- } \\
\text { cerides } \\
\text { (mg/100 ml serum }\end{array}$} \\
\hline & & & $\begin{array}{l}\text { Whole } \\
\text { Serum }\end{array}$ & \multicolumn{2}{|c|}{ Fractions } & $\begin{array}{c}\text { Ratio } \\
\text { LDL/HDL } \\
\end{array}$ & $\begin{array}{l}\text { Whole } \\
\text { Serum }\end{array}$ & \multicolumn{2}{|c|}{ Fractions } & $\begin{array}{c}\text { Ratio } \\
\text { LDL/HDL }\end{array}$ & \\
\hline $\begin{array}{l}\text { Normal } \\
\text { Subjects }\end{array}$ & $\begin{array}{r}\text { C-1 } \\
2 \\
3 \\
4 \\
5 \\
6 \\
7 \\
8 \\
\text { Averag } \\
\text { (tstandard } \\
\end{array}$ & $\begin{array}{ll}42 & \mathrm{~m} \\
33 & \mathrm{~m} \\
38 & \mathrm{~m} \\
37 & \mathrm{~m} \\
29 & \mathrm{~m} \\
39 & \mathrm{f} \\
42 & \mathrm{f} \\
34 & \mathrm{f} \\
1 \sim 8 \\
\text { iation) } \\
\end{array}$ & $\begin{array}{l}224 \\
220 \\
201 \\
228 \\
174 \\
215 \\
188 \\
259 \\
214 \\
\left( \pm 26^{3}\right) \\
\end{array}$ & $\begin{array}{r}78 \\
45 \\
60 \\
61 \\
55 \\
76 \\
42 \\
85 \\
63 \\
( \pm 16) \\
\end{array}$ & $\begin{array}{l}146 \\
175 \\
141 \\
167 \\
119 \\
139 \\
146 \\
174 \\
151 \\
( \pm 20) \\
\end{array}$ & $\begin{array}{c}1.88 \\
3.89 \\
2.34 \\
2.72 \\
2.15 \\
1.83 \\
3.48 \\
2.05 \\
2.54 \\
( \pm 0.77) \\
\end{array}$ & $\begin{array}{l}231 \\
195 \\
206 \\
185 \\
200 \\
267 \\
178 \\
249 \\
214 \\
( \pm 32) \\
\end{array}$ & $\begin{array}{r}130 \\
78 \\
108 \\
82 \\
116 \\
153 \\
87 \\
141 \\
112 \\
( \pm 28) \\
\end{array}$ & $\begin{array}{r}101 \\
117 \\
98 \\
103 \\
84 \\
114 \\
91 \\
108 \\
102 \\
( \pm 11) \\
\end{array}$ & $\begin{array}{c}0.78 \\
1.50 \\
0.91 \\
1.26 \\
0.72 \\
0.75 \\
1.05 \\
0.77 \\
0.97 \\
( \pm 0.28) \\
\end{array}$ & $\begin{array}{r}85 \\
96 \\
57 \\
114 \\
57 \\
150 \\
67 \\
78 \\
88 \\
( \pm 32) \\
\end{array}$ \\
\hline \multirow[t]{2}{*}{$\begin{array}{c}\text { Hyperlipidemia } \\
\text { (Type II b) }\end{array}$} & $\begin{array}{r}\mathrm{H}-1 \\
2 \\
3 \\
4 \\
5 \\
6 \\
7\end{array}$ & $\begin{array}{ll}54 & \mathrm{~m} \\
42 & \mathrm{~m} \\
49 & \mathrm{f} \\
46 & \mathrm{f} \\
67 & \mathrm{f} \\
51 & \mathrm{~m} \\
39 & \mathrm{~m}\end{array}$ & $\begin{array}{l}243 \\
249 \\
285 \\
221 \\
229 \\
329 \\
275\end{array}$ & $\begin{array}{l}34 \\
34 \\
64 \\
25 \\
32 \\
43 \\
35\end{array}$ & $\begin{array}{l}209 \\
215 \\
221 \\
196 \\
197 \\
286 \\
240\end{array}$ & $\begin{array}{l}6.15 \\
6.32 \\
3.48 \\
7.84 \\
6.16 \\
6.65 \\
6.86\end{array}$ & $\begin{array}{l}253 \\
202 \\
423 \\
208 \\
231 \\
320 \\
244\end{array}$ & $\begin{array}{r}83 \\
63 \\
185 \\
60 \\
72 \\
88 \\
63 \\
\end{array}$ & $\begin{array}{l}170 \\
169 \\
238 \\
148 \\
159 \\
232 \\
181\end{array}$ & $\begin{array}{l}2.05 \\
2.68 \\
1.29 \\
2.47 \\
2.21 \\
2.63 \\
2.87\end{array}$ & $\begin{array}{l}223 \\
231 \\
169 \\
162 \\
221 \\
527 \\
363\end{array}$ \\
\hline & \multicolumn{2}{|c|}{$\begin{array}{c}\text { Average H } 1 \sim 7 \\
\text { (tstandard deviation) }\end{array}$} & $\begin{array}{l}262 * \\
( \pm 38)\end{array}$ & $\begin{array}{l}38 * * \\
( \pm 13)\end{array}$ & $\begin{array}{l}223 * * * \\
( \pm 31)\end{array}$ & $\begin{array}{l}6.21 * * * \\
( \pm 1.34)\end{array}$ & $\begin{array}{l}269 \\
( \pm 78)\end{array}$ & $\begin{array}{c}88 \\
(+44)\end{array}$ & $\begin{array}{l}185 * * * \\
( \pm 35)\end{array}$ & $\begin{array}{l}2.31 * * * \\
( \pm 0.53)\end{array}$ & $\begin{array}{l}271 * * \\
( \pm 130)\end{array}$ \\
\hline Hyperlipidemia & $\mathrm{H}-8$ & $32 \mathrm{f}$ & 366 & 40 & 326 & 8.15 & 259 & 67 & 192 & 2.87 & 121 \\
\hline (Type II a) & 9 & $16 f$ & 1003 & 21 & 982 & 46.8 & 619 & 36 & 583 & 16.2 & 401 \\
\hline Miscellaneous & $\begin{array}{r}\mathrm{H}-10 \\
11 \\
12\end{array}$ & $\begin{array}{ll}61 & \mathrm{~m} \\
46 & \mathrm{f} \\
60 & \mathrm{f}\end{array}$ & $\begin{array}{l}182 \\
382 \\
232\end{array}$ & $\begin{array}{l}42 \\
52 \\
28\end{array}$ & $\begin{array}{l}140 \\
330 \\
204\end{array}$ & $\begin{array}{l}3.33 \\
6.35 \\
7.28\end{array}$ & $\begin{array}{l}231 \\
274 \\
197\end{array}$ & $\begin{array}{r}102 \\
75 \\
72\end{array}$ & $\begin{array}{l}129 \\
199 \\
125\end{array}$ & $\begin{array}{l}1.26 \\
2.65 \\
1.74\end{array}$ & $\begin{array}{l}255 \\
125 \\
164\end{array}$ \\
\hline
\end{tabular}

$*_{P}<0.02, * *_{P}<0.01, \star \star \star P P<0.001$ against the normal subjects, HDL: High density lipoprotein fraction

LDL: Low density lipoprotein fraction

the same results. The analysis of samples from lecithin was performed on a column of $10 \%$ polyethylene-glycol succinate on Chromosorb $\mathrm{W}$ at $190^{\circ}$. The response of polyusaturated fatty acids was satisfactory $\left(98 \%\right.$ at $184^{\circ}$ and $96.6 \%$ at $196^{\circ}$ for $1 \mu \mathrm{g}$ of C 22:6 compared with the response of $\mathrm{C}$ $18: 1)$.

\section{RESULTS}

1) Serum concentration of cholesterol and phospholipids and their distribution between lipoprotein fractions

Concentration of total cholesterol, phospholipids and triglycerides in whole serum and the distribution of cholesterol and phospholipids between HDL and LDL fractions were shown in Table 1 . The distribution ratio of serum cholesterol, $\mathrm{LDL} / \mathrm{HDL}$, was $2.54( \pm 0.77)$ for normal subjects. Among 9 cases with coronary heart disease and allied disorders followed in this study, seven had type IIb hyperlipidemia and the other two had type IIa hyperlipidemia with xanthomatosis. The mean value of serum cholesterol concentration of type IIb patients was $262 \mathrm{mg} / 100$ ml. Although the value was not so significantly high compared with the value for normal subjects $(0.01<\mathrm{P}<0.02)$, the amount of cholesterol in HDL fraction from $100 \mathrm{ml}$ blood serum (HDL-cholesterol) was significantly decreased and the amount of cholesterol in LDL fraction (LDL-cholesterol) increased, so that the distribution ratio of cholesterol, LDL/HDL, showed a marked elevation in this group of patients (6.21士 1.34): ( $\mathrm{P}<0.001$ vs normal control).

Three miscellaneous cases, one with hyperlipidemia and hypothyroidism under treatment with thyroid extract, another with alcoholic hyperlipemia at remission stage, and the third with sequelae of cerebral hemorrhage, were also used in this study. Although the last case was normolipidemic, the distribution ratio of cholesterol, LDL/ HDL, was markedly increased (case H-12).

\section{2) Fatty acid composition of lecithin in} HDL and LDL fractions

There was essentially no difference in fatty acid composition of lecithin between HDL and LDL, except slight differences in concentration of oleate $(18: 1)$, linoleate $(18: 2)$ and arachidonate $(20: 4)$ (Table 2). 
Table 2. Fatty acid composition of phosphatidylcholine in high and low density lipoprotein fractions in blood serum

\begin{tabular}{|c|c|c|c|c|c|c|}
\hline \multirow{2}{*}{ Fatty acids $\star^{1}$} & \multicolumn{2}{|c|}{ Case $C-1$} & \multicolumn{2}{|c|}{ Case $\mathrm{C}-2$} & \multicolumn{2}{|c|}{ Case $C-4$} \\
\hline & $\mathrm{HDL} \star^{2}$ & $L D L \star^{3}$ & HDL & LDL & HDL & LDL \\
\hline $14: 0$ & 0.48 & 0.1 & 0.3 & 0.3 & 0.3 & 0.3 \\
\hline $16: 0$ & 34.5 & 33.7 & 32.4 & 32.9 & 35.7 & 35.7 \\
\hline 1 & 1.3 & 1.5 & 1.2 & 0.9 & 0.7 & 0.7 \\
\hline $18: 0$ & 17.7 & 16.9 & 15.6 & 16.0 & 16.3 & 16.4 \\
\hline 1 & 15.0 & 15.2 & 11.8 & 12.3 & 12.4 & 13.3 \\
\hline 2 & 23.4 & 24.8 & 24.3 & 25.2 & 19.6 & 19.8 \\
\hline $20: 3(w-6)$ & 0.7 & 0.5 & 1.4 & 1.3 & 1.3 & 1.4 \\
\hline $4(w-6)$ & 5.4 & 4.1 & 6.7 & 4.7 & 9.0 & 8.3 \\
\hline $5(w-3)$ & 0.3 & 0.8 & 1.6 & 1.7 & 0.6 & 0.5 \\
\hline $22: 3(w-9)$ & 0.3 & 0.4 & 2.1 & 1.6 & 1.9 & 1.7 \\
\hline
\end{tabular}

Lecithin in HDL-fraction was slightly richer in polyunsaturated fatty acid $(20: 4)$ than lecithin in LDL-fraction.

3) Fatty acid composition of sphingomyelin in lipoprotein fractions from normal subjects

Palmitate $(16: 0)$ and nervonate $(24: 1)$ were major fatty acids of sphingomyelin in blood serum. The sum of the concentration of these two fatty acids attained to more than half of the total fatty acid in sphingomyelin (Table 3 ).

The concentration of $24: 1$ was higher in HDL than in LDL fraction, while the con-

Table 3. Fatty acid composition of sphingomyelin in serum high and low density lipoprotein fractions in normal subjects

\begin{tabular}{|c|c|c|c|}
\hline \multirow{2}{*}{$\begin{array}{c}\text { Fatty acids } \\
\text { (Carbon chain length } \\
\text { : degree of unseturation' }\end{array}$} & \multicolumn{3}{|c|}{ Normal subjects (C 1-8) } \\
\hline & $\mathrm{HDL} \star^{1}$ & $L D L \star^{2}$ & $\begin{array}{l}\text { difference } \\
\text { between } \\
H D L \text { and } L D L\end{array}$ \\
\hline $16: 0$ & $23.8 \pm 2.7 \star^{3}$ & $32.3 \pm 3.7$ & $P<0.001$ \\
\hline $18: 0$ & $7.3 \pm 1.7$ & $8.6 \pm 1.4$ & \\
\hline 1 & $3.4 \pm 1.9$ & $1.6 \pm 0.8$ & \\
\hline $20: 0$ & $4.2 \pm 0.4$ & $4.1 \pm 0.5$ & \\
\hline 1 & $0.5 \pm 0.2$ & $0.4 \pm 0.3$ & \\
\hline $21: 0$ & $0.6 \pm 0.2$ & $0.5 \pm 0.1$ & \\
\hline $22: 0$ & $10.4 \pm 1.8$ & $9.6 \pm 1.6$ & \\
\hline 1 & $3.1 \pm 2.2$ & $2.3 \pm 2.0$ & \\
\hline $23: 0$ & $3.7 \pm 0.9$ & $3.5 \pm 0.5$ & \\
\hline 1 & $1.0 \pm 0.6$ & $0.7 \pm 0.3$ & \\
\hline $24: 0$ & $7.2 \pm 1.9$ & $6.6 \pm 2.0$ & \\
\hline 1 & $34.9 \pm 3.4$ & $29.4 \pm 4.4$ & $P<0.02$ \\
\hline sum of $22: 0 \sim 24: 1$ & $60.2 \pm 2.2$ & $52.1 \pm 4.1$ & $P<0.001$ \\
\hline $16: 0 / 24: 1$ & $0.69 \pm 0.13$ & $1.14 \pm 0.30$ & $P<0.005$ \\
\hline $\begin{array}{l}16: 0 / 24: 1 \text { ratio } \\
\text { between LDL/HDL }\end{array}$ & \multicolumn{3}{|c|}{$1.65 \pm 0.30$} \\
\hline
\end{tabular}

centration of 16:0 was higher in LDL than in HDL fraction. In general, fatty acids with longer carbon chain were concentrated in HDL much more than in LDL fraction, so that the concentration of the long chain fatty acids with carbon chain length no less than 22 in HDL fraction was significantly higher than that in LDL fraction.

\section{4) Fatty acid composition of sphingomyelin in hyperlipidemia}

In patients with hyperlipidemia of Type IIa and IIb, the difference in fatty acid composition of sphingomyelin between HDL and LDL fractions was less marked than in normal subjects (Table 4, Fig. 1). There was a tendency for the average chain length becoming shorter in HDL fraction, while it becoming slightly longer in LDL fraction in hyperlipidemics compared with normal subjects.
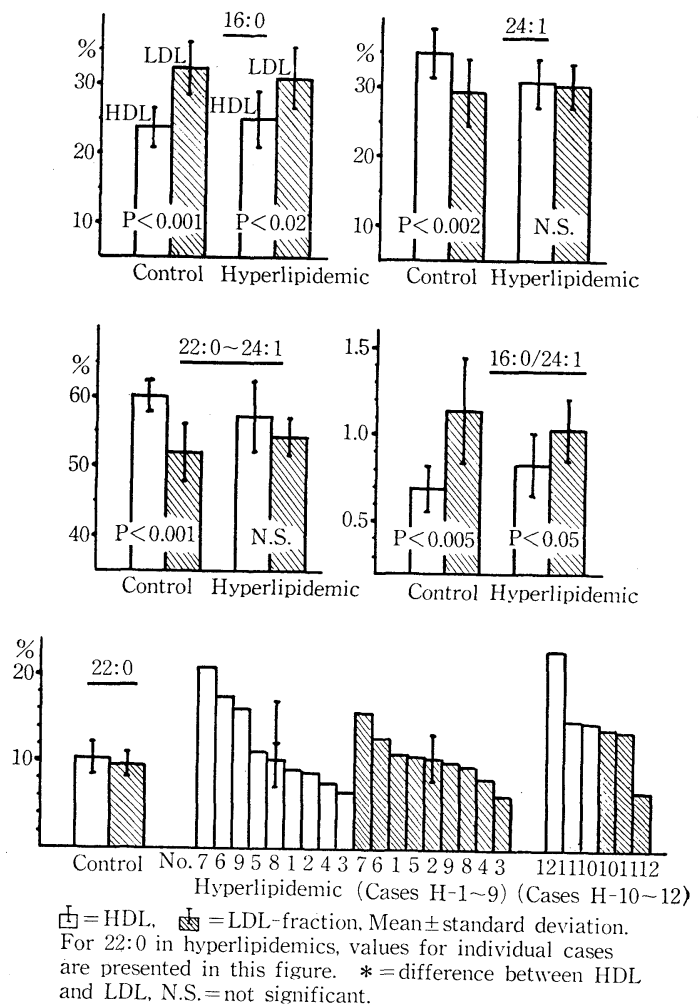

Fig. 1. Fatty acid composition of sphingomyelin in serum lipoprotein fractions from normal and hvperlipidemic subjects. 
Table 4. Fatty acid composition of sphingomyelin in serum high and low density lipoprotein fractions in hyperlipidemics

\begin{tabular}{|c|c|c|c|c|c|c|c|c|}
\hline \multirow{3}{*}{ Fatty acids $*^{1}$} & \multirow{2}{*}{\multicolumn{2}{|c|}{ Hyperlipidemics $(\mathrm{H}-\mathrm{l} \sim 9)$}} & \multicolumn{6}{|c|}{ Miscellaneous cases } \\
\hline & & & \multicolumn{2}{|c|}{ Case $\mathrm{H}-10$} & \multicolumn{2}{|c|}{ Case $\mathrm{H}-\mathrm{II}$} & \multicolumn{2}{|c|}{ Case $\mathrm{H}-12$} \\
\hline & $\mathrm{HDL} \star^{2}$ & LDL * ${ }^{3}$ & HDL & LDL & HDL & LDL & HDL & LDL \\
\hline $16: 0$ & $25.0 \pm 3.9$ & $30.9 \pm 4.2$ & 25.0 & 39.2 & 22.5 & 32.3 & 26.8 & 42.1 \\
\hline $18: 0$ & $8.6 \pm 2.2$ & $8.6 \pm 2.1$ & 5.5 & 4.6 & 5.6 & 7.6 & 6.8 & 10.4 \\
\hline 1 & $4.0 \pm 1.4$ & $1.1 \pm 0.8$ & 5.1 & 1.0 & 3.3 & 0.6 & 0.6 & 0.9 \\
\hline $20: 0$ & $3.5 \pm 0.9$ & $4.1 \pm 0.6$ & 3.4 & 3.4 & 3.0 & 4.8 & 2.4 & 3.0 \\
\hline 1 & $0.8 \pm 0.5$ & $0.5 \pm 0.7$ & 1.0 & 0.2 & 0.5 & 0.3 & - & 0.3 \\
\hline $21: 0$ & $0.8 \pm 0.3$ & $0.6 \pm 0.3$ & 0.6 & 0.2 & 0.5 & 0.4 & 1.5 & 0.3 \\
\hline $22: 0$ & $12.1 \pm 4.9$ & $10.6 \pm 2.7$ & 15.3 & 14.1 & 15.4 & 13.8 & 23.0 & 6.7 \\
\hline 1 & $5.1 \pm 2.6$ & $4.1 \pm 1.9$ & 1.5 & 1.0 & 3.7 & 2.2 & 6.5 & 2.1 \\
\hline $23: 0$ & $3.1 \pm 0.9$ & $2.8 \pm 0.6$ & 3.9 & 4.1 & 4.1 & 4.1 & 1.4 & 1.2 \\
\hline 1 & $0.6 \pm 0.7$ & $0.6 \pm 0.5$ & 0.6 & 0.2 & 0.6 & 0.2 & 0.1 & 0.3 \\
\hline $24: 0$ & $5.8 \pm 1.9$ & $6.0 \pm 1.8$ & 14.3 & 12.1 & 11.4 & 8.0 & 0.7 & 2.5 \\
\hline 1 & $30.7^{\circ} \pm 3.4$ & $30.3 \pm 3.0$ & 23.8 & 19.9 & 29.4 & 25.7 & 30.2 & 30.2 \\
\hline $\begin{array}{c}\text { Sum of } \\
22: 0-24: 1\end{array}$ & $57.4 \pm 4.9$ & $54.4 \pm 2.6$ & 59.4 & 51.4 & 64.6 & 54.0 & 61.9 & 43.0 \\
\hline \multirow{2}{*}{$\begin{array}{c}16: 0 / 24: 1 \\
\text { Ratio bet- } \\
\text { ween LDL/HDL }\end{array}$} & \multirow{2}{*}{\multicolumn{2}{|c|}{$0.83 \pm 0.181 .03 \pm 0.18$}} & 1.05 & 1.97 & 0.77 & 1.26 & 0.89 & 1.39 \\
\hline & & & \multicolumn{2}{|c|}{$(1.88)$} & \multicolumn{2}{|c|}{$(1.64)$} & \multicolumn{2}{|c|}{$(1.56)$} \\
\hline \multicolumn{9}{|c|}{$\begin{array}{l}\star^{1} \text { Carbon chain length: degree of unsaturation } \\
\left.\star^{2} \text { High density lipoprotein fraction (HDL }+V H D L\right) \\
\star^{3} \text { Low density lipoprotein fraction (LDL + VLDL) } \\
\star^{4} \text { Percent of total fatty acids ( } \pm \text { standard deviation) }\end{array}$} \\
\hline
\end{tabular}

The major change in distribution of fatty acids in hyperlipidemics appeared in HDL fraction as a decrease in $24: 1$. Compared with a marked difference between HDL and HDL fractions observed in normal subjects, there was almost no difference in the total amount of fatty acids with chain length 22-24 in hyperlipidemics between the two fractions.

In some of the cases of hyperlipidemia (case 6, 7 and 9), there was a marked increase in concentration of behenic acid (22:0) especially in HDL fraction. All of these cases had the serum triglyceride concentration higher than $300 \mathrm{mg} / 100 \mathrm{ml}$. The variation in concentration of 22:0 in LDL fraction was not so significant as in HDL fraction.

5) Changes in fatty acid composition of sphingomyelin in hyperlipidemics by treatment with hypocholesterolemic agents

Treatment of hyperlipidemics with a derivative of nicotinic acid, nicomol (2, 2,

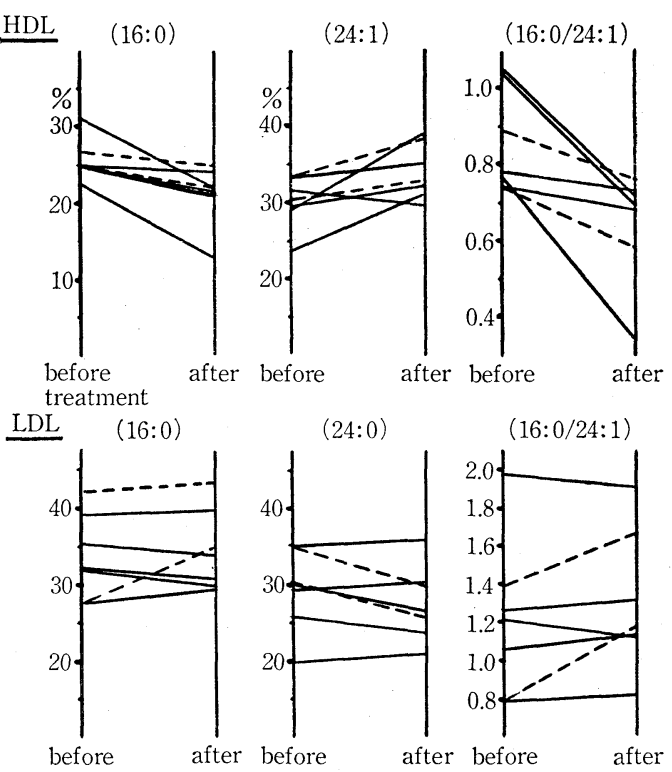

Fig. 2. Effects of nicomol and estrogen on fatty acid composition of sphingomyelin in HDL and LDL-fractions.

- treatment with nicomol

- - treatment with estrogen 
6, 6-tetrakis (nicotinyloxymethyl) - cyclohexanol), or estrogens increased the concentration of $24: 1$ with a decrease of 16:0. The ratio of $16: 0$ to $24: 1$ was significantly decreased, so that the distribution pattern of fatty acids in lipoprotein fractions was normalized (Fig. 2). The change took place mainly in HDL and there was no effect of nicomol on the fatty acid composition of sphingomyelin in LDL fraction. But, estrogens had also an effect on LDL fraction, decreasing the concentration of $24: 1$ and increasing the concentration of 16:0.

\section{6) The change in concentration of $22: 0$ in relation to the change in serum triglyce- ride level}

A long term administration of nicomol often causes a significant increase in concentration of triglyceride in blood serum and enhances alcohol-induced hyperlipidemia. As the triglyceride level going up by treatment with nicomol, the concentration of 22:0 was also increased. Including the three cases mentioned before, in which the

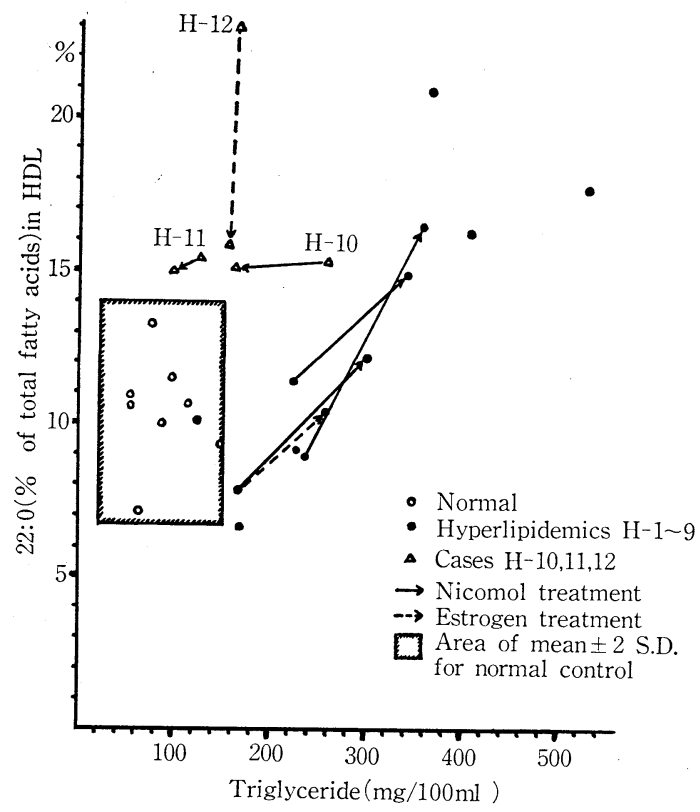

Fig. 3. Relationship between serum triglyceride level and the concentration of behenate (22: 0) in sphingomyelin in HDL fraction. triglyceride concentration was originally high, all the cases with triglyceride level higher than $300 \mathrm{mg} / 100 \mathrm{ml}$ had a concentra. tion of 22:0 signifieantly higher than the control value (Fig. 3).

Three miscellaneous cases showed an increase of $22: 0$ in spite of the normal triglyceride level. A case with alcoholic hyperlipidemia (case $\mathrm{H}-10$ ) and another with sequeale of cerebral hemorrhage (case $\mathrm{H}-12$ ) were even normocholesterolemic, but the ratio of LDL to HDL-cholesterol was higher than the control value. The other case was under treatment with thyroid hormone. In case $\mathrm{H}-12$, the administration of estrogen resulted in a marked decrease in concentration of $22: 0$.

\section{DISCUSSION}

Fractions of lipoproteins in blood serum have different phospholipid composition. HDL is rich in lecithin and LDL contains a larger amount of sphingomyelin than $\mathrm{HDL}^{1,2)}$. The molar ratio of lecithin to sphingomyelin is about 7 for HDL and 2 for LDL. There is a close association between sphingomyelin and cholesterol and a linear relationship was obtained for whole serum which was shown by a formula $[$ Cholesterol $]=31+4.3$ [Sphingomyelin $]^{3}$.

Complex lipids show a characteristic distribution for each fraction of subcellular particles ${ }^{5)}$. Cardiolipin, for example, is specific for mitochondria, and cerebroside for myelin in nervous system. Sphingomelin is a complex lipid which is specific to the surface membrane, and shares the presence in this structure with phosphatidylserine and cholesterol ${ }^{4,5,9)}$. Red cell membrane, blood vessels and nervous tissue are typical examples for the kind of tissues predominantly composed of the surface membrane and consequently relatively rich in these $\operatorname{lipids}^{5}$. Lipids in serum lipoproteins seem to be slightly peculiar in this sence because it is rich in sphingomyelin and cholesterol, but contains no phosphatidylserine. However, it is not so far to say that the coating membrane of plasma lipoproteins is a 
kind of remnant of the surface membrane.

One of the peculiar characteristics of sphingolipids is the content of long chain fatty acids with chain length more than $20^{9-11,25-28)}$. Among these fatty acids, nervonic acid $(24: 1)$ is the commonest component. In nervous tissue it is shown that this fatty acid increased its concentration continuously during the course of development ${ }^{25-28)}$. It was suggested that long chain fatty acids are needed for stabilizing the membrane structure ${ }^{29}$. In cerebrosides in the adult brain, long chain fatty acids with carbon chain length 20-26 occupy about 90\% of total fatty acids ${ }^{10,26-28)}$. A question arises why palmitate $(16: 0)$ or stearate $(18: 0)$ are also present in large amounts in sphingomyelin showing a hiatus between 16:0 (or 18:0) and $24: 1$.

Only a few information is available concerning the fatty acid composition of sphingomyelin in lipoprotein fractions of human blood serum ${ }^{30-32}$. According to the present results, there was a marked difference in fatty acid composition of sphingomyelin between HDL and LDL fractions. In normal subjects, HDL contains a larger amount of long chain fatty acids than LDL. In contrast to sphingomyelin, there was essentially no difference in fatty acid composition of lecithin. Lecithin in serum moves very easily between HDL and $\mathrm{LDL}^{33-35)}$ and also shows an easy exchange with lecithin in tissue such as liver ${ }^{36)}$. But, it was reported that the exchange of sphingomyelin between HDL and LDL as well as between tissue and plasma is not so fast nor complete as the movement of lecithin between lipoprotein classes or between tissue and plasma $^{25,36)}$. Such a difference must be related to the selection of molecular species for membrane structure.

Compared with normal subjects, the difference in fatty acid composition of sphingomyelin between HDL fractions was not marked in hyperlipidemics. The change was mainly due to the decrease in concentration of long chain fatty acids in HDL fraction. This could be explained in the following way. In normal subjects, the synthesis of $24: 1$ was relatively in excess compared with the rate of synthesis of cholesterol. LDL seems to be very strict for selecting the molecular species of sphingomyelin. The surplus of the long chain fatty acid was incorporated into HDL so that the variation in fatty acid composition of sphingomyelin was larger in HDL fraction than in LDL. In hyperlipidemia, there was an increased demand for long chain fatty acids as a component of LDL, and consequently, the incorporation of $24: 1$ into HDL was relatively decreased. The increase in 22:0 must be to compensate for the deficiency in $24: 1$. The abnormally high values of $22: 0$ in our miscellaneous cases, especially in cases $\mathrm{H}-10$ and 12, pointed out a covered profile of hyperlipidemia which could not be traced by total serum cholesterol level. It is suggested that the rate of synthesis of sphingomyelin with a long chain fatty acid is a complemental factor for the development of hyperlipidemia.

ACKNOWLEDGEMENTS: This work was supported in part by grants from Daiwa Health Foundation and Medical Research Foundation for Adult Diseases.

\section{REFERENCES}

1) Skipski VP, Barclay M, Barclay KR, Fetzer VA, Good JJ, Archibald FH : Lipid composition of human serum lipoproteins. Biochem J 104 : 340-352, 1967.

2) Yamamoto A: Phospholipids and their fatty acid composition in hyperlipemia. J Jap Soc Intern Med 63 : 1155-1159, 1973 (in Jap, abst in Engl)

3) Yamamoto A, Ishikawa K, Uhara S, Adachi S, Nishikawa M: Relationship between serum lipid components in hyperlipemia. J Biochem (Tokyo) 74:59-65, 1973.

4) Dod BJ, Gray GM: The lipid composition of rat liver plasma membranes. Biochim Biophys Acta 150 : 397-404, 1968.

5) Rouser G, Yamamoto A, Kritchevsky G: Cellular membranes, Structure and regulation of lipid class composition, species differences, changes with age, and variations in 
some pathological states. Arch Intern Med 127 : 1105-1122, 1971.

6) Buch RG, Rossiter RJ: Lipids of normal and atherosclerotic aortas Arch Pathol 51: 224-237, 1951.

7) Böttcher CJF, VanGent GM: Changes in the composition of phospholipids and phospholipid fatty acids associated with atherosclerosis in the human aortic wall. J Atheroscl Res 1:36-46, 1961.

8) Rouser G, Solomon RD: Changes in phospholipid composition of human aorta with age. Lipids 4 : 232-234, 1969.

9) Ray TK, Skipski VP, Barclay M, Essner E, Archibald FM: Lipid composition of rat liver plasma membranes. J Biol Chem 244 : 5528-5536, 1969.

10) Gerstl B, Eng LF, Hayman RB, Tavastsjerna MG, Bond PR: On the composition of humanmyelin. J Neurochem 14:661-670, 1967.

11) Karlsson KA, Samuelsson BE, Stein GO : Detailed structure of sphingomyelins and ceramides from different regions of bovine kidney with special reference to long chain bases. Biochim Biophys Acta 316: 336-362, 1973.

12) Sinensky $\mathbf{M}$ : Homeoviscous adaptation-a homeostatic process that regulates the viscosity of membrane lipids in escherichia coli Proc Natl Acad Sci US 71 : 522-525, 1974.

13) Huang C, Lorch SK, Smith GG, Huang A : Control of membrane lipid fluidity in acholeplasma laidlawii. FEBS Lett $43: 1-5,1974$.

14) Burstein M, Scholnick HR: Lipoproteinpolyanion-metal interactions. Adv Lipid Res 11: 68-108, 1973.

15) Srinivasan SR, Radhakrishnamurphy B, Berenson GS: Studies on the isolation of heparin with serum lipoproteins in the presence of $\mathrm{Ca}^{2+}, \mathrm{Mg}^{2+}$ and $\mathrm{Mn}^{2+}$. Arch Biochem Biophys 170 : 334-340, 1975.

16) Wilson DE, Speiger MJ: A dual precipitation method for quantitative plasma lipoprotein measurement without ultracentrifugation. J Lab Clin Med 82: 473-482, 1973.

17) Ishikawa TT, Brazier JB, Steiner PM, Stewart LE, Gartside PS, Glueck CJ : A study of the heparin-manganese chloride method for determination of plasma lipoprotein cholesterol concentration. Lipids 11: 628-633, 1976.

18) Folch Pi, Lees M, Sloan-Stanley GH: A simple method for the isolation and purification of total lipides from animal tissues
J Biol Chem 226: 497-509, 1957.

19) Zurkowski P: Cholesterol determination with a single reagent. Clin Chem 10:451453, 1964.

20) Chen PS, Jr, Toribara TY, Warner H: Microdetermination of phosphorus. Anal Chem 28 : 1756-1758, 1956.

21) Rouser G, Siakotos AN, Fleischer AN : Quantitative analysis of phospholipids by thin-layer chromatography and phosphorus analysis of spots. Lipids $1: 85-86,1966$.

22) Rouser G, Kritchevsky G, Yamamato A : Column chromatographic and associated procedures for separation and determination of phosphatides and glycolipids in "Lipid Chro. matographic Analysis" Vol 1. (Marinetti GVed) Marcel-Dekker, Inc, New York, p 99$162,1967$.

23) Yamamoto A, Adachi S: TLC analysis of phospholipids. Jap J Clin Chem $1: 154-167$, 1972 (in Jap)

24) Dawson RMC: Analysis of phosphatides and glycolipids by chromatography of their partial hydrolysis or alcoholysis products, in "Lipid Chromatographic Analysis" Vol 1 (Marinetti GV ed) Marcel-Dekker, Inc, New York, p 163-189, 1967.

25) Ställberg-Stenhagen S, Svennerholm L: Fatty acid composition of human brain sphingomyelins: normal variation with age and changes during myelin maturation. J Lipid Res 6 : 146-155, 1965.

26) Svennerholm L, Ställberg-Stenhagen S : Changes in the fatty acid composition of cerebrosides and sulfatides of human nervous tissue with age. J Lipid Res 9: 215-225, 1968.

27) O'Brien JS, Sampson EL: Fatty acid and fatty aldehyde composition of the major brain lipids in normal human gray matter, white matter and myelin. J Lipid Res 6: 545-551, 1965.

28) Rouser G, Yamamoto A : Lipids in "Hand. book of Neurochemistry" Vol 1 (Lajtha A ed) Plenum Press, New York, p 121-169, 1969.

29) Vandenheuvel FA: Biological structure at the molecular level with stereomodal projections (I) The lipids in the myelin sheath of nerve. J Amer Oil Chem Soc 40:455472, 1963.

30) Wood P, Imaichi K, Knowles J, Michaels G, Kinsell L: The lipid composition of human plasma chylomicrons. J Lipid Res 
5 : 225-231, 1964.

31) Jones JW, Ways PJ : Abnormalities of high density lipoproteins in abeta-lipoproteinemia. J Clin Invest 46: 1151-1161, 1964.

32) Nelson G: Studies on human serum lipoprotein phospholipids and phospholipid fatty acid composition by silicic acid chromatography. J Lipid Res 3 : 71-79, 1962.

33) Florsheim WH, Morton ME: Stability of phospholipid binding in human serum lipoproteins. J Appl Physiol 10: 301-304, 1957.
34) Minari O, Zilversmit DS : Behavior of dog lymph chylomicron lipid constituents during incubation with serum. J Lipid Res 4 : 424436, 1963.

35) Illingworth DR, Portman OW: Exchange of phospholipids between low and high density lipoproteins of squirrel monkeys. J Lipid Res 13 : 220-227, 1972.

36) Zilversmit DB: Exchange of phospholipid classes between liver microsomes and plasma : comparison of rat, rabbit and guinea pig. J Lipid Res 12: 36-42, 1971. 